\title{
PENGARUH RASIO HARGA KEUNTUNGAN, RASIO KEUNTUNGAN SETIAP LEMBAR SAHAM, RASIO PENGEMBALIAN ASET, DAN RASIO HUTANG ATAS MODAL TERHADAP HARGA SAHAM PADA SEKTOR INDUSTRI BARANG KONSUMSI YANG LISTING DI BEI TAHUN 2015-2019
}

\author{
Etty Lutfiyati, Alean Kistiani, dan Milka Susana Theorupun \\ Program Studi Akuntansi \\ Fakultas Ekonomi \\ Universitas Boyolali
}

e-mail: ettylutfi97@gmail.com, alean.kistiani@gmail.com, m.susana.theorupun@gmail.com

\begin{abstract}
ABSTRAK
Sasaran dalam penelitian ini yaitu perusahaan sektor industri barang konsumsi. Dengan metode purposive samplingdiperoleh 29 sampel.Selama lima periode observasi diperoleh 145 data sekunder yang kemudian diolah dalam SPSS. Rasio harga keuntungan berpengaruh positif tapi tidak signifikan, dikarenakan nilai signifikan lebih besar dari 0,05 yaitu 0,734 dan thitung 0,340. Harga saham secara parsial dipengaruhi oleh rasio keuntungan setiap lembar saham dan rasio pengembalian aset yang signifikan dan positif, diketahui dari nilai t hitung 5,634 dan 8,728 serta signifikan 0,000. Rasio hutang atas modalberpengaruh negatif dan tidak signifikan karena nilai signifikansi lebih besar dari 0,05 yaitu 0,403 dan t hitung - 0 . Secara simultan Rasio harga keuntungan, rasio keuntungan seriap lembar saham, rasio pengembalian aset dan rasio hutang atas modalmemiliki pengaruh yang signifikan terhadap harga saham, dengan signifikansi 0,05 dan nilai F 4,062.
\end{abstract}

Kata kunci : Harga Saham, Rasio Harga Keuntungan, Rasio Hutang Atas Modal, Rasio Keuntungan Setiap Lembar Saham, Rasio Pengembalian Aset.

\begin{abstract}
The target in this study is the consumer goods industry sector company. With the purposive sampling method obtained 29 samples. During the five observation periods, 145 secondary data were obtained which were then processed in SPSS. The profit price ratio has a positive but insignificant effect, because the significant value is greater than 0.05, namely 0.734 and t count 0.340. Share price is partially influenced by the profit ratio of each share and the ratio of return on assets which is significant and positive, it is known from the t-count value of 5,634 and 8,728 and significant 0,000. Debt to equity ratio has a negative and insignificant effect because the significance value is greater than 0.05, namely 0.403 and t count - 0 . Simultaneously, the profit price ratio, profit ratio of each share, asset return ratio and debt to equity ratio have a significant effect on stock prices, with a significance of 0.05 and a value of 4.062 .
\end{abstract}

Keywords:Stock Price, Profit Price Ratio, Debt to Equity Ratio, Profit Ratio for Each Share, Asset Return Ratio.

\section{Pendahuluan}

Saat ini, di Indonesia terdapat sebuah lembaga yang menyelenggarakan fasilitas sistem untuk mempertemukan penawaran jual atau beli efek antar perusahaan maupun perorangan, dengan tujuan untuk memperdagangkan efek perusahaan-perusahaan yang telah tercatat di Bursa Efek Indonesia. Perusahaan ini terdiri dari sektor pertanian, sektor keuangan, sektor pertambangan, sektor industri barang konsumsi dan lain sebagainya. Pada penelitian ini, peneliti memilih sektor 
industri barang konsumsi karena seluruh sub sektor indusrti barang konsumsi merupakan produsen dari produk kebutuhan dasar manusia, seperti makanan, minuman, obat, kosmetik, keperluan rumah tangga dan peralatan rumah tangga.

Berdasarkan data PT Bursa Efek Indonesia, kinerja sektor consumerturun 19,11 \%sepanjang kuartal 1/2020. Penurunan ini merupakan yang paling tipis diantara sektor lainnya. Kepala Riset Samuel Sekuritas, Suria Dharma mengatakan adanya imbauan untuk berkegiatan dari rumah menyebabkan konsumsi barang meningkat, kemungkinan menjadi salah satu sentiment positif yang menyongkong kinerja sektor consumer. Menurut data Bloombarg, saham PT Siantar Top tbk (STTP) menjadi penompang untuk sektor barang konsumsi dengan kenaikkan 44,44\% sepanjang 1/2020. Kemudian saham ITIC (40,38 persen), INAF (24,14 persen) dan KAEF (4,80 persen). Kehadiran dua emiten farmasi ini dinilai tak mengherankan karena keduanya memang produsen produk kesehatan serta obat dan vitamin yang kini diburu oleh masyarakat. Selain itu, Indofarma juga menjadi salah satu perusahaan yang bertanggung jawab akan alat kesehatan untuk penanganan Covid-19 di Indonesia seperti impor 100.000 paket rapid test dari China dan Korea (m.Bisnis.com)

Menurut ${ }^{[2]}$ nilai perusahaan dapat dilihat dari harga saham perusahaan. Tingginya nilai suatu perusahaan mengakibatkan harga suatu saham semakin mahal. Untuk menilai prestasi perusahaan diperlukan analisis menggunakan rasio-rasio ${ }^{[3]}$. Rasio yang digunakan antara lainrasio harga keuntungan, rasio keuntungan setiap lembar saham, rasio pengembalian aset dan rasio hutang atas modal. Rasio untuk melihat pertumbuhan laba terhadap harga saham dinamakan rasio harga keuntungan. Rasio keuntungan setiap lembar saham berfungsi sebagai kira-kira potensi keuntungan dari setiap lembar sahamnya. Dalam melihat pemanfaatan aset untuk mendapatkan keuntungandiperlukan rasio pengembalian aset. Rasio hutang atas modaldigunakan untuk melihat risiko perusahaan dari total utang.

Penelitian ini dilakukan untuk melihat bagaimana pengaruh secara bersama-sama maupun parsial antararasio harga keuntungan, rasio keuntungan setiap lembar saham, rasio pengembalian aset, dan rasio hutang atas modal terhadap harga saham.

Dari uraian tersebut, peneliti tertarik dengan penelitian yang berjudul:"PENGARUHRASIO HARGA KEUNTUNGAN, RASIO KEUNTUNGAN SETIAP LEMBAR SAHAM, RASIO PENGEMBALIAN ASET, DAN RASIO HUTANG ATAS MODAL TERHADAP HARGA SAHAM PADA SEKTOR INDUSTRI BARANG KONSUMSI YANG LISTING DI BEI TAHUN 2015-2019".

\section{Tinjauan Pustaka}

\subsection{Tinjauan Pustaka}

Undang-undang Pasar Modal No. 8 Tahun 1995 mengartikan pasar modal sebagai“kegiatan yang bersangkutan dengan penawaran umum dan perdagangan efek, perusahaan publik yang berkaitan dengan efek yang diterbitkannya, serta lembaga profesi yang berkaitan dengan efek". Sarana pembiayaan bagi perusahaan dan lembaga lain, serta sarana kegiatan untuk berinvestasi dinamakan pasar modal (http://www.idx.co.id). Bursa Efek Indonesiamerupakan gabungan dari BES dan BEJ.

Menurut Undang-undang No. 40 tahun 2007 "benda bergerak dan meberikan hak suara dalam RUPS adalah saham". Sedangkan dalam http://www.idx.co.id saham yaitu "penyertaan modal dari seseorang atau instansi pada suatu perusahaan, kemudian instansi memiliki klaim atas pendapatan perusahaan, dan berhak hadir dalam RUPS". Menurut [4] saham ada dua macam:

\section{Common Stock}

Common Stock merupakan saham yang sering disebut dalam pasar ekuitas. Pemegang saham biasa mendapatkan hak suara dalam RUPS

2. Saham Preferen

Saham preferen merupakan sekuritas yang menyertakan kepemilikan dan mendapatkan deviden tetapi saham preferen tidak mempunyai hak suara pada RUPS.

Harga saham adalah harga yang didapat dari penawaran dan permintaan pasar modal. Ketika permintaan lebih besar, harga saham naik; ketika emisi saham lebih besar, harga 
saham turun ${ }^{[5]}$. Ada beberapa jenis harga saham,antara lain harga tertinggi, harga terendah, harga nominal, harga awal, harga pasar, harga pembukaan, harga rata-rata dan harga penutupan.Harga saham penutupan pada tanggal 28 Desember 2015-2019 yang digunakan oleh peneliti. Harga saham selalu berfluktuasi, sehingga investor harus memperhatikan indikator yang dapat mempengaruhi harga saham. Indikator dapat berasal dari faktor eksternal dan internal, termasuk faktor eksternal yaitu: Fluktuasi nilai tukar mata uang, kebijakaan pemerintah dsb. Sedangkan indikator internalnya antara lain:

1. Laba bersih perusahaan

2. Jumlah asset yang dimiliki oleh perusahaan

3. Total ekuitas

4. Jumlah saham yang beredar

5. Total kewajiban yang ditanggung oleh perusahaan.

Indikator-indikator diatas kemudian bisa dianalisis memakai rasio harga keuntungan.

Rasio keuntungan setiap lembar saham, rasio pengembalian aset dan rasio hutang atas ekuitas.Dalam analisis suatu perusahaan, menurut ${ }^{[4]}$ faktor utama yang dapat diperhatikan adalah rasio keuntungan setiap lembar saham dan rasio harga keuntungan. Karenarasio keuntungan setiap lembar saham dan rasio harga keuntungan menunjukkan informasi terkait laba suatu perusahaan yang akan dibagikan kepada investor.

Rasio yang berguna untuk mengukur harga suatu saham atas kelipatan earning disebut rasio harga keuntungan. Contoh, rasio harga keuntungan suatu perusahaan adalah 10, maka harga sahamnya 10 kali lipat dariearnings perusahaan. Jika earnings tahunan dibagikan dalam bentuk deviden, maka nilairasio harga keuntungan10 kali menunjukkan lama investasi pembelian saham akan kembali dalam waktu 10 tahun. Dengan demikian, nilai kelipatan kecil menunjukkan lama investasi dan kembali semakin cepat $\left.{ }^{[6}\right]$.Harapan penyetor modal terhadap keuntungan perusahaan pada masa depan, direleksikan pada harga saham yang investor siap bayarkan, dan selanjutnya mempengaruhi rasio harga keuntungan perusahaan. Analis dapat memperkirakan layak atau tidaknya saham suatu perusahaan untuk dibeli $^{[5]}$.

Perusahaan dengan tingkat pertumbuhan yang lebih tinggi, dapat dilihat dari tingginya nilai rasio harga keuntungan, berarti pasar mengharapkan kenaikan keuntungan dimasa datang. nilai kecil, maka semakin murah harga suatu saham dan layak untuk dibeli karena berpotensi naik dimasa depan ${ }^{[7]}$. Rasio harga keuntungan bisa didapatkan dari ikhtisar saham dan laporan laba rugi. Secara sistematis, rumus untuk menghitung rasio ini adalah sebagai berikut:

$$
\text { Rasio harga keuntungan }=\frac{\text { Harga Saham }}{\text { Keuntungan setiap lembar Saham }}
$$

Rasio keuntungan setiap saham adalah ukuran keberhasilan profitabilitas manajemen. Semakin besar laba per lembar sahamnya maka keuntungan yang diperoleh investor juga besar[6].Rasio keuntungan setiap lembar sahammerupakan rasio keuntungan dimana dari nilai rasio ini kita bisa menilai berapa potensi laba yang akan kita dapatkan. biasanya tercatat dalam laporan keuangan, meski sebagian perusahaan tidak mencatatnya,Rasio keuntungan setiap lembar saham dapat dihitung dari:

$$
\text { Rasio keuntungan setiap lembar saham }=\frac{\text { Keuntungan Bersih }}{\text { Jumlah Saham yang Beredar }}
$$

Menurut ${ }^{[8]}$ rasio pengembalian aset yaiturasio dimana aset perusahaan digunakan demi memperoleh laba.Semakin tinggi rasio pengembalian aset akan semakin baik profitabilitas produktivitas aset, yang akan menarik minat investor terhadap saham perusahaan dimasa yang akan dating ${ }^{[9]}$. Rasio ini dapat diketahui dari perbandingan:

$$
\text { Rasio Pengembalian Aset }=\frac{\text { Laba Bersih Setelah Pajak }}{\text { Total Asset }}
$$


Rasio hutang atas modal rasio untuk memeriksa modal perusahaan, digunakan sebagai jaminan hutang ${ }^{[6]}$. Rasio hutang atas modal termasuk dalam rasio solvabilitas. Sehingga investor akan lebih berminat pada perusahaan yang mempunyairasio hutang atas ekuitas rendah.Jika nilai rasio hutang terhadap harga saham tinggi, Hal ini karena jika perusahaan memperoleh laba, maka perusahaan akan menggunakan laba tersebut untuk melunasi hutangnya, daripada membagikan dividen kepada investor ${ }^{[10]}$. Rasio ini juga dapat digunakan untuk menilai resiko suatu perusahaan. Rasio hutang atas modal diperoleh dari neraca dengan perhitungan :

$$
\text { Rasio Hutang atas Modal }=\frac{\text { Total Utang }}{\text { Total Ekuitas }}
$$

\subsection{Penelitian Terdahulu}

Wenda Pramanda (2017) dalam penelitiannya "PengaruhPrice earning ratio, earning per share, return on asset dan debt to equity ratioTerhadap Harga Saham Perusahaan Manufaktur Sektor Industri Barang Konsumsi yang Terdaftar di Bursa Efek Indonesia Periode 2013-2015". Price earning ratio, earning per share, return on asset dan debt to equity ratiosecara bersama-sama atau sebagian berdampak positif pada harga saham.

Wuri Handayani dkk (2017) dalam penelitian "Pengaruh Return On Asset,Earning Per Share, Debt to Equity Ratio, Debt to Asset Rasio dan Current Rasio Terhadap Harga Saham Studi Empiris Perusahaan Manufaktur Industri Barang Konsumsi yang Terdaftar di Bursa Efek Indonesia Tahun 2013-2015”. Alhasil ROA, EPS, DER, DAR dan CR secara simultan berpengaruh positif terhadap harga saham. Harga saham tidak dipengaruhi oleh return on asset, debt-to-equity ratio, dan debt-to-asset ratio, tetapi dipengaruhi oleh laba per saham dan rasio lancar.

Kesamaan antara dua penelitian diatas dengan penelitian iniyaitu objek berupa sektor industri barang konsumsi, memakai variabel bebas berupa EPS, PER, ROA serta DER. Sedangkan untuk perbedaannya yaitu penelitian diatas menggunakan periode pengamatan tiga tahun, rasio DAR dan CR dipakai dalam penelitian Wuri ${ }^{[9]}$.

\subsection{Kerangka Pemikiran}

Untuk mengetahui adanya pengaruh antaraantara variabel dependen dan variabel independen, dimana Rasio harga keuntungan sebagai X1, Rasio keuntungan setiap lembar sahamsebagai X2, Rasio pengembalian asetsebagai X3, Rasio hutang atas modal sebagai X4 dan harga saham sebagai Y. Maka dibutuhkan data dari laporan tahunan yang kemudian data tersebut dapat diperiksa sesuai sistem dan prosedur yang berlaku.

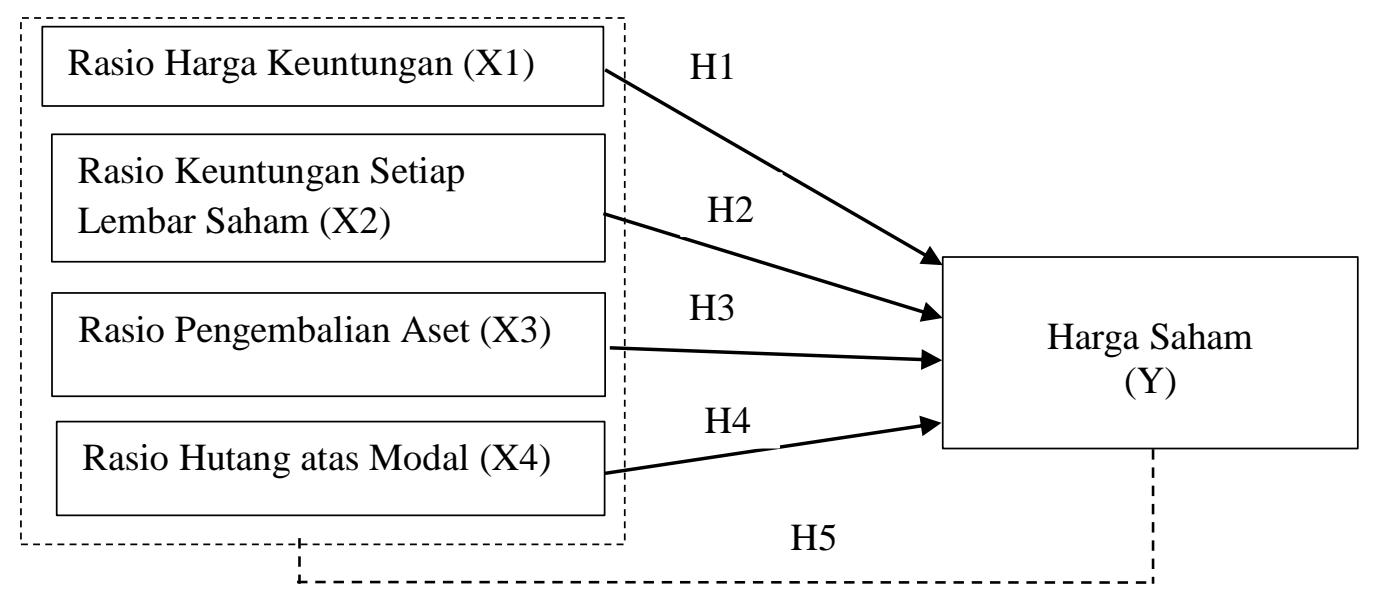

Gambar 1. Kerangka Pemikiran 


\section{Metode Penelitian}

Jumlah populasi penelitian ini adalah 55 perusahaan industri barang konsumsi, kemudiandiperoleh 29 perusahaan sampel, pengambilan sampel ini diperoleh dari metode purposive sampling. Adapun kriteria dari purposive sampling yaitu:

1. Industri barang konsumsi yang pada tahun 2015-2019 telah dan masih tercatat di BEI

2. Industri barang konsumsi yang dari tahun 2015 sampai 2019 aktif memperdagangkan saham nya.

3. Perusahaan yang terus melaporkan laporan tahunan yang mengakomoadasi laporan keuangan yang sudah diaudit selama periode pengamatan, yaitu 2015 sampai 2019.

4. Perusahaan yang 5 tahun berturut-turut tidak dalam keadaan merugi.

Penelitian ini tergolong penelitian kuantitatif. Data yang digunakan adalah data pembantu dari http://www.idx.co.id. Dalam penelitian ini digunakan uji hipotesis klasik yang harus lolos, karena dapat memastikan persamaan regresi dalam estimasi tidak bias. Kemudian melakukan uji regresi linier berganda, hipotesis (uji t dan F) dan uji kepastian.

\section{Hasil dan Pembahasan}

Penelitian ini mengunakan uji hipotesis klasik yang harus lolos, karena dapat memastikan persamaan regresi dalam estimasi tidak biasSetelah dilakukan pengujian antara variabel independen serta variabel dependen tidak memenuhi kriteria pengujian asumsi klasik,Sehingga diperlukan transformasi data. Transformasi data merupakan salah satu cara untuk menormalkan data dengan merubah skala pengukuran data asli yang masih memiliki nilai sama sehingga dapat memenuhi kriteria uji asumsi klasik [11]. Sehinggan dilakukan transformasi data terhadap variabel dependen kedalam bentuk LN. Variabel dependen ditransformasi menjadi harga saham (LN_Y).

Tabel 1.

Hasil uji regresi linier berganda dan uji t antara rasio harga keuntungan, rasio keuntungan setiap lembar saham, rasio pengembalian aset, dan rasio hutang atas modal terhadap harga saham

\begin{tabular}{rlrrr}
\hline Model & & \multicolumn{1}{l}{ Beta } & \multicolumn{1}{l}{$t$} & \multicolumn{1}{l}{ Sig. } \\
& & & & \\
\hline & (Constant) & 6.615 & 36.997 & .000 \\
1 & PER & .001 & .340 & .734 \\
& EPS & .000 & 5.634 & .000 \\
& ROA & 8.891 & 8.728 & .000 \\
& \multicolumn{2}{l}{ Sumber: Data Output SPSS yang diolah, 2020 }
\end{tabular}

Dari tabel diatas, diperoleh persamaan regresi berganda sebagai berikut:

$$
\mathrm{Y}=6,615+0,001 . \mathrm{X} 1+0,000 \cdot \mathrm{X} 2+8,891 \cdot \mathrm{X} 3+-0,061 \cdot \mathrm{X} 4
$$

Nilai kostanta positif 6,615. Hasil ini menunjukkan harga saham (LN_Y) akan bernilai sebesar 6,615 apabila rasio harga keuntungan, rasio keuntungan setiap lembar saham, rasio pengembalian aset, dan rasio hutang atas modaladalah 0 . Nilai koefisien rasio harga keuntunganadalah positif 0,001 , yang artinya harga saham (LN_Y)akan naik 0,001 jika rasio harga keuntunganmengalami peningkatan $1 \%$. Rasio keuntungan setiap lembar sahammempunyai nilai konstanta sebesar 0,000 , artinya harga saham (LN_Y)akan bernilai tetap saatrasio keuntungan setiap lembar sahammengalami peningkatan 1\%.Nilai koefisienrasio pengembalian aset adalah positif 8,891 , artinya harga saham (LN_Y) meningkat 
sebesar 8,891 apabila rasio pengembalian aset juga mengalami peningkatan. Koefisienrasio hutang atas modalbernilai negatif 0,061, artinya meskipun rasio hutang atas ekuitas mengalami peningkatan, harga saham (LN_Y) tetap menurun 8,891 .

Nilai t hitungrasio harga keuntungan yaitu 0,340 dengan signifikan 0,734 lebih besar dari 0,05.Maka dapat dinyatakan bahwa rasio harga keuntunganmemiliki pengaruh yang positif namun tidak signifikan. Yang berati dalam melihat kondisi pasar, rasio harga keuntungantidak dapat digunakan patokan, karena para investor mengutamakan patokan dari rasio keuntungan setiap lembar saham dan rasio pengembalian aset. Namun investor tetap harus memperhatikannya karena dari hasil pengujian t nya bernilai positif sehingga jika rasio harga keuntungannaiki harga saham tentu akan naik juga [12].

Rasio keuntungan setiap lembar sahamberdampak positif serta signifikan, sebab nilai signifikani nya 0,000 dan t hitung 5,634. Tinggi rendahnya keuntungan diperoleh investor ditunjukkan dengan nilai rasio keuntungan setiap lembar sahamnya. Sehingga rasio keuntungan setiap lembar sahamyang tinggi akan diminati oleh investordan mengakibatkan harga saham naik [1].Hasil ini sama dengan penelitian [9].

Nilai t hitungrasio pengembalian aset sebesar 8,728 dan siginifakan 0,000.Artinya rasio pengembalian aset terhadap harga saham (LN_Y) berpengaruh positif dan signifikan,Jika perusahaan ingin meningkatkan nilai pengembalian aset, maka perusahaan dapat meningkatkan penjualan / pendapatan bersih dengan cara meningkatkan efisiensi semua aktivitas perusahaan atau mengurangi pendapatan dan HPP. Selain itu, perusahaan juga dapat mempertimbangkan untuk menginvestasikan sebagian dananya pada produk investasi yang menguntungkan[1]. Penelitian yang sesuai dengan hasil ini dilakukan oleh[13].

Rasio hutang atas modal berpengaruh negatif juga tidak signifikan dengan harga saham (LN_Y), dikarenakan nilai signifikan 0,403 yang lebih besar dari 0,05 dan t hitung 0,839.Nilai rasio hutang atas modalmenujukkan tingkat hutang suatuperusahaan. Harga saham rendah jika utang perusahaan tinggi, karena dibandingan dengan membagikan deviden perusahaan mengutamakan untuk membayar utangnya terlebih dahulu[10].Penelitian [5] sejalan dengan penelitian ini.

Tabel 2.

Hasil uji Fantara rasio harga keuntungan, rasio keuntungan setiap lembar saham, rasio pengembalian aset, dan rasio hutang atas modal terhadap harga saham

\begin{tabular}{llcc}
\hline Model & & $F$ & Sig. \\
\hline \multirow{4}{*}{1} & Regression & 27.439 & $.000^{\mathrm{b}}$ \\
& Residual & & \\
& Total & & \\
\hline
\end{tabular}

Sumber: Data Output SPSS yang diolah, 2020

Berdasarkan hasil pengujian diatas, F hitungnya adalah sebesar 27,439 dengan nilai signifikan 0,000.Rasio harga keuntungan, rasio laba per saham, pengembalian aset dan rasio hutang atas modal semuanya berdampak pada harga saham (LN_Y). Menurut uji determinasi nilainya adalah 43,9\%. Dengan demikian, untuk 43,9\%, harga saham dipengaruhi oleh rasio harga keuntungan, rasio laba per saham, pengembalian aset dan rasio hutang atas modal.

\section{Kesimpulan}

Rasio harga keuntungan, rasio keuntungan setiap lembar saham dan rasio pengembalian assetberpengaruh positif dengan harga saham, tapi pengaruh yang paling signifikan adalah rasio keuntungan setiap lembar saham, rasio pengembalian aset.Pada saat yang sama, rasio hutang atas modal berdampak negatif serta tidak signifikandengan harga saham.Rasio harga keuntungan, rasio keuntungan setiap lembar saham, rasio pengembalian aset, dan rasio hutang atas modalberdampak positif dengan harga saham pada industri barang konsumsi yang tercatat di BEI tahun 2015-2019. 
Keterbatasan penelitian ini adalah:Tahun observasi yang digunakan masih sangat singkat yaitu lima tahun, sehingga hasil penelitian mungkin kurang representatif. Penelitian ini baru menggunakan Rasio harga keuntungan, rasio keuntungan setiap lembar saham, rasio pengembalian aset dan rasio hutang atas modalsebagai variabel bebas, padahal ada rasio lain yang dapat mempengaruhi harga saham.

Bagi penelitian selanjutnya diharapkan untuk menambah tahun observasi atau menggunakan variabel bebas yang lain. Hasil dari penelitian ini adalah terdapat hubungan yang positif antara rasio harga keuntungan, rasio keuntungan setiap lembar saham, rasio pengembalian dengan harga saham. Sehingga calon investor sehingga calon investor harus lebih memperhatikan rasio ini sebelum berinvestasi. Pada saat yang sama, bagi perusahaan, yang terbaik adalah meningkatkan keuntungan mereka untuk meningkatkan harga saham perusahaan.

\section{DAFTAR PUSTAKA}

[1] Dewi, W. P. “Analisis Pengaruh Earning Per Share (EPS), Price Earning Ratio (PER), Debt to Equity Ratio (DER) dan Return On Asset (ROA) Terhadap Harga Saham Pada Perusahaan Manufaktur Sektor Industri Barang Konsumsi yang Terdaftar di Bursa Efek Indonesia Periode 2013”, Simki-economic, Vol. 01, No. 03, pp. 1-14, 2017.

[2] Yakub,M. R. “Jurnal Pengaruh Earning Per Share ( EPS ), Return on Asset ( ROA ) Dan Debt To Equity Ratio ( DER ) Terhadap Harga Saham Pada Perusahaan Manufaktur Yang Terdaftar Di Bursa Efek Indonesia Tahun 2013-2015”, Vol. 01, No. 08, 2017.

[3] Fahlevi,I. R.“Pengaruh Rasio Likuiditas, Profitabilitas Dan Solvabilitas Terhadap Harga Saham (Studi Empiris Pada Industri Perbankan Yang Terdaftar Di Bursa Efek Indonesia Tahun 2008-2010)", pp. 1-102, 2013.

[4] Eduardus Tandelilin, Pasar Modal Manajemen Portofolio \& Investasi. Yogyakarta: PT Kanisius, 2017.

[5] S. S. dan W. Afriyenis, "Analisis Fundamental Terhadap Harga Saham Perusahaan Manufaktur Sektor Industri Barang Konsumsi Sigit Sanjaya”, J. Kaji. Ekon. Islam, Vol. 3, 2018.

[6] Putri, A.M. "Pengaruh Earning Per Share (EPS), Price Earning Ratio (PER), Dan Debt To Equity Ratio (DER) Terhadap Harga Saham Pada Perusahaan Kosmetik Dan Rumah Tangga Yang Terdaftar Di Jakarta Islamic Index (JII)", Skripsi UIN Raden Fatah, p. 30, 2017.

[7] E. Novasari, "Pengaruh Per, Eps, Roa Dan Der Terhadap Harga Saham Perusahaan Sub-Sektor Industri Textile Yang Go Public Di Bursa Efek Indonesia (BEI) Tahun 2009-2011", Vol. 134, No. 4. 2013.

[8] Kasmir, Analisis Laporan Keuangan. Depok: Rajawali Pers, 2019.

[9] P. A. R. \& A. E. R. Handayani, Wuri. "Pengaruh Return On Asset (Roa),Earning Per Share (Eps),Debt To Equity Rasio (Der),Debt To Asset Rasio (Dar),Dan Current Rasio (Cr) Terhadap Harga Saham (Studi Empiris Perusahaan Manufaktur Sektor Industri 
Barang Konsumsi Yang Terdapat Di Bursa Efek Indonesia”, J. Chem. Inf. Model., Vol. 53, No. 9, pp. 1689-1699, 2013.

[10] Rimbani, R. P. “Analisis Pengaruh ROE, EPS, PBV, DER, Dan NPM Terhadap Harga Saham Pada Perusahaan Real Estate Dan Property Di Bursa Efek Indonesia (BEI) Periode 2011-2013", Akuntansi, Vol. 53, No. 12, pp. 182-228, 2016.

[11] I. Ghozali, Analisis Multivariate dengan SPSS. Semarang: Universitas Diponegoro, 2016.

[12] Hidayat, W.dan P. H. "Pengaruh Earning Per Share (Eps), Price Earning Ratio (Per), Debt To Equity (Der), Return on Asset (Roa), Dan Return on Equity (Roe) Terhadap Harga Saham Studi Kasus Pada Perusahaan Go Public Sektor Property Dan Real Estate Yang Terdaftar Di Bursa Efek Indonesia", J. Ilmu Adm. Bisnis, Vol. 5, No. 3, pp. 28-41, 2016.

[13] Fasbiyanti, Nurul Afifah, R. M. W. dan M. R., "Pengaruh Return On Assets (ROA), Return ON Equity (ROE) Dan Earning Per Share (EPS) Terhadap Harga Saham (Studi Empiris Pada Perusahaan Manufaktur Di Sektor Industri Barang Konsumsi Yang Terdaftar Di Bursa Efek Indonesia Tahun 2016-2017).," pp. 15-16, 2020, [Online].


ذو وي ن\&option=com_dbook\&task=readonline\&book_id=13650\&page=73\&chkhashk=E D9C9491B4\&Itemid=218\&lang=fa\&tmpl=component. 